\title{
RENOVATION AND STRENGTHENING OF WOODEN BEAMS WITH CFRP BANDS INCLUDING THE RHEOLOGICAL EFFECTS
}

\author{
Krzysztof KULA ${ }^{1}$, Tomasz SOCHA ${ }^{2}$ \\ University of Zielona Gora, Zielona Góra, Poland
}

\begin{abstract}
The paper presents a work analysis of wooden beams reinforced with glued composite bands from the top and resin inclusions, taking into account the rheology of materials. The paper presents numerical model of the multimaterial beam work including rheological phenomena described by linear equations of viscoelasticity. For the construction of this model one used MES SIMULIA ABAQUS environment in which were prepared its own procedures containing rheological models. The calculation results were compared with the literature data. One has done an analysis of the advisability of the use of CFRP reinforcements bands in terms of rheological phenomena.
\end{abstract}

Keywords: ABAQUS, CFRP, wood, resin inclusion, composites, layered structures, MES, crawling, rheology, strengthening

\section{INTRODUCTION}

An important problem in the restoration and strengthening of wooden beams, especially in historic buildings, is to maintain their authenticity. To preserve valuable pieces of wood, especially the polychrome or sculptured, which, due to

\footnotetext{
${ }^{1}$ Corresponding author: University of Zielona Gora, Faculty of Building, Architecture and Environmental Engineering, Z. Szafrana st 1, 65-516 Zielona Góra, Poland, e-mail: k.kula@ib.uz.zgora.pl, tel. +48683284788

2 Corresponding author: University of Zielona Gora, Faculty of Building, Architecture and Environmental Engineering, Z. Szafrana st 1, 65-516 Zielona Góra, Poland, e-mail: s.socha@ib.uz.zgora.pl, tel. +48683282271
} 
their high historical and aesthetic values, cannot be replaced, new methods of restoration and strengthening are required. Methods for maintaining appearance and dimensions and not interfering architectural design with reinforcing elements [6].

With the help to solve these difficult problems come new structural materials in the form of bands of various types of composites and adhesives based on various kinds of synthetic resins [1].

Method which preserves the original dimensions and historical value of wooden beams is to paste in the milled deep channels, from the top of the wood, fibrecomposite bands combined with a reinforced element using glue. Due to the large size of the channels associated with technological considerations and a small thickness of produced bands one obtains a very thick glue line, de facto resin inclusion, which can also play an important strengthening role in special cases even on their own, without the band [6].

Pasting bands inside cross-section and from above not only solves the problems of preservation but it is also beneficial for strength reasons. Limited is the possibility of delaminating at the meeting point of the band - wood, a substantial part of the element cross-section undergoes bridging, which automatically eliminates the influence of defects in the wood. There are also important issues of fire resistance. The available research shows that hiding bands inside the section increases the strength of the tested beams of glued laminated timber during fire attempts by $44 \%$ compared to the beams reinforced with external reinforcement [2].

The article presents an analysis of wooden beams deflections reinforced with glued CFRP bands from the top, made of carbon fibre in terms of rheological phenomena. Rheology problems have so far been overlooked, one focused mainly on calculating load capacity and stiffness increases with short-term load. Indeed, in this type of strengthening these increases tend to be significant, but the rheological phenomena may change this image. They are also a cause of substantial redistribution of stresses within the multimaterial section.

This article is only preliminary and fact-finding. Numerical calculations were made based on the results presented in the works [2] and [5]. One has also not dealt with work issues of the element before reinforcing and the impact of rheological phenomena occurring at this stage. This problem is especially important with respect to the reinforcing of the element having a long history of load. The authors hope to introduce discussion of such problems in future publications. 


\section{MATERIALS AND RHEOLOGICAL MODEL}

Wood properties strongly dependent on its anatomical directions. In the case of beam decisive is the direction along the fibres. Elastic parameters were adopted in accordance with the values given in [2]. To strengthen the wood was used CFRP band Sika CarboDur S1512. While to the combination of wood with band one used adhesive composition based on epoxy resin Epidian E57 and hardener Z1. The elastic parameters were summarized in Table 1.

Table 1. Elastic parameters of used materials

\begin{tabular}{|c|l|l|}
\hline \multicolumn{1}{|c|}{ Material } & materials constant & the numerical value \\
\hline \multirow{4}{*}{ WOOD } & $\mathrm{E}_{1}$ & $7800 \mathrm{MPa}$ \\
\cline { 2 - 3 } & $\mathrm{E}_{2}$ & $800 \mathrm{MPa}$ \\
\cline { 2 - 3 } & $\mathrm{E}_{3}$ & $800 \mathrm{MPa}$ \\
\cline { 2 - 3 } & $\mathrm{V}_{12}$ & 0,4 \\
\cline { 2 - 3 } & $\mathrm{v}_{13}$ & 0,025 \\
\cline { 2 - 3 } & $\mathrm{V}_{23}$ & 0,4 \\
\cline { 2 - 3 } & $\mathrm{G}_{12}$ & $600 \mathrm{MPa}$ \\
\cline { 2 - 3 } & $\mathrm{G}_{13}$ & $600 \mathrm{MPa}$ \\
\cline { 2 - 3 } & $\mathrm{G}_{23}$ & $600 \mathrm{MPa}$ \\
\hline BAND & $\mathrm{E}$ & 0,25 \\
\cline { 2 - 3 } CFRP Sika CarboDur S1512 & $\mathrm{V}$ & $2430 \mathrm{MPa}$ \\
\hline \multirow{2}{*}{ GLUE } & $\mathrm{E}$ & 0,25 \\
\cline { 2 - 3 } & $\mathrm{v}$ & \\
\hline
\end{tabular}

To describe the rheology of wood and glue one adopted five-parameter rheological model shown in Fig. 1. It is assumed that the CFRP band does not show rheological properties, which requires further study and confirmation.

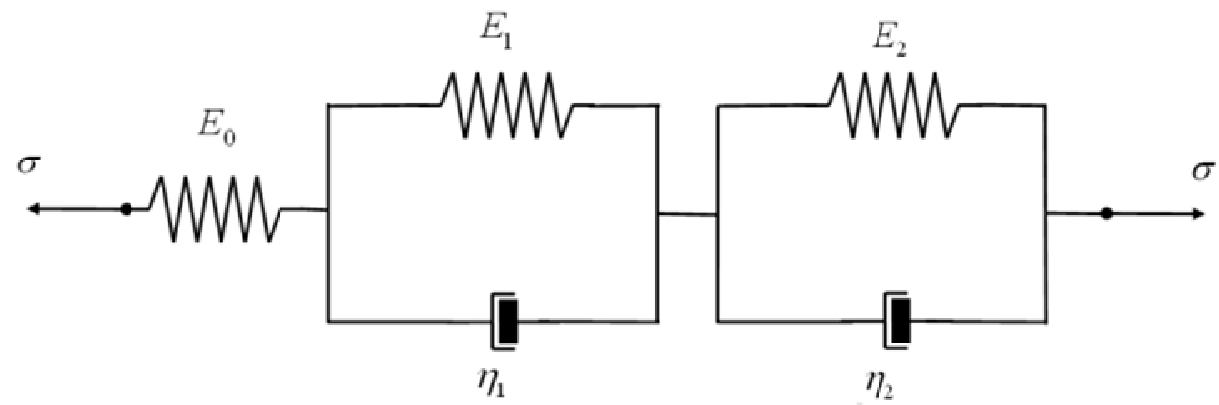

Fig. 1. Five-parameter rheological model 
Relaxation function takes the form of:

$$
\begin{gathered}
E(t)=\frac{1}{p_{2} \cdot \rho_{1} \cdot \rho_{2}} \cdot\left\{q_{0}-\frac{1}{\rho_{2}-\rho_{1}} \cdot\left[\rho_{2} \cdot e^{\rho_{1} \cdot t} \cdot\left(q_{0}+q_{1} \cdot \rho_{1}+q_{2} \cdot \rho_{1}^{2}\right)-\right.\right. \\
\left.\left.+\rho_{1} \cdot e^{\rho_{2} \cdot t} \cdot\left(q_{0}+q_{1} \cdot \rho_{2}+q_{2} \cdot \rho_{2}^{2}\right)\right]\right\},
\end{gathered}
$$

where

$$
\begin{gathered}
\rho_{1}=\frac{1}{2 \cdot p_{2}} \cdot\left[-p_{1}+\left(p_{1}^{2}-4 \cdot p_{2} \cdot p_{0}\right)^{\frac{1}{2}}\right], \\
\rho_{2}=\frac{1}{2 \cdot p_{2}} \cdot\left[-p_{1}-\left(p_{1}^{2}-4 \cdot p_{2} \cdot p_{0}\right)^{\frac{1}{2}}\right], \\
p_{0}=E_{0} \cdot E_{2}+E_{1} \cdot E_{2}+E_{0} \cdot E_{1}, p_{1}=\left(E_{0}+E_{1}\right) \cdot \eta_{2}+\left(E_{2}+E_{0}\right) \cdot \eta_{1}, p_{2}=\eta_{1} \cdot \eta_{2} \\
q_{0}=E_{0} \cdot E_{1} \cdot E_{2}, q_{1}=E_{0} \cdot\left(E_{1} \cdot \eta_{2}+E_{2} \cdot \eta_{1}\right), q_{2}=E_{0} \cdot \eta_{1} \cdot \eta_{2} .
\end{gathered}
$$

Parameter $E$ and $\eta$ of this model was calculated using the results of their research samples of each of these materials and the method of least squares. These issues will be developed in the work [5].

\section{RESULTS}

The work considers one way to strengthen, in the proposed specific literature. Analyzed way of introducing composite strengthening to the work structure is particularly useful in places where the three surfaces of the timber are exposed and we expect them to remain intact. In the aforementioned paper [2], the authors carried out experimental studies and numerical analysis in the elastic field for such beams, as well as for several other ways to strengthen and for beam made of solid wood. In the cited example, next to an elastic analysis induced by momentary load we also analyze the rheological properties of reinforced structural element. Static beam scheme and the cross-section with dimensions are shown in Figure 2, and material data are summarized in Table 1. The used composite band has a length equal to the length of the beam, the width of $150 \mathrm{~mm}$ and a thickness of $1.2 \mathrm{~mm}$. 

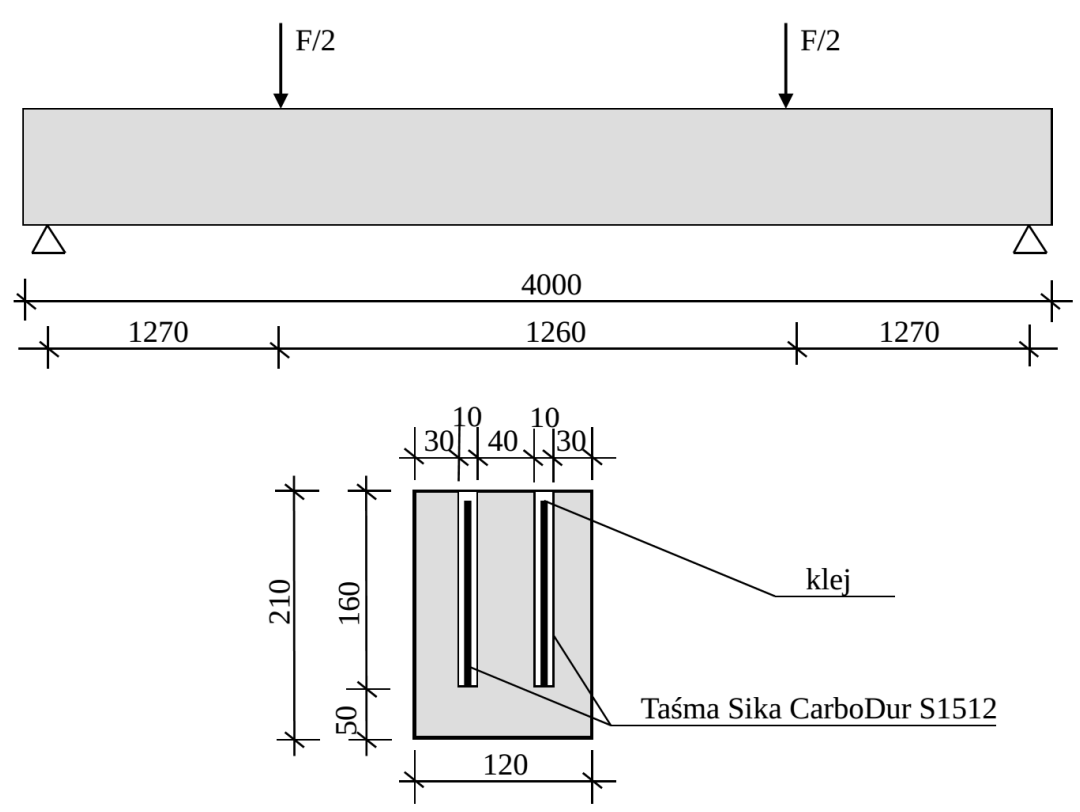

Fig. 2. Static scheme of analyzed structural element (top) and a reinforced beam section (bottom). Dimensions are given in millimetres

Numerical model was prepared on the basis of MES Abaqus system and independently written in FORTRAN procedure UMAT (User-defined MATerial) containing the relationship between stress and deformation for fiveparameter rheological model in the form of Jacobian (5.1) [4]:

$$
\mathrm{C}=\frac{\delta \Delta \sigma}{\delta \Delta \varepsilon}
$$

To build the Jacobian (5.1) one used a central differential operator and differential equation model of constitutive five-parameter model (5.2):

$$
p_{0} \cdot \sigma+p_{1} \cdot \dot{\sigma}+p_{2} \cdot \ddot{\sigma}=q_{0} \cdot \varepsilon+q_{1} \cdot \dot{\varepsilon}+q_{1} \cdot \ddot{\varepsilon} .
$$

Each beam element (wood, glue, and band) was modelled as a separate part (PART). The individual parts (PART) were combined using the TIE function. Cubic finite element C3D8R and comparatively C3D20R were applied. The implemented numerical model is consistent with the assumptions of the mechanics of layered structures presented in the works [3] and [5].

\subsection{Analysis with momentary loads}

Numerical analysis in the range of momentary loads was carried out for force $\mathrm{F}$ of $30 \mathrm{kN}$. The calculations were made for both solid wood beam (dimensions 
the same as reinforced beam), as well as reinforced beams. The maximum deflection of the beam in the middle of the span amounted to $18.5 \mathrm{~mm}$ (solid beam) and $12.2 \mathrm{~mm}$ (reinforced beam)

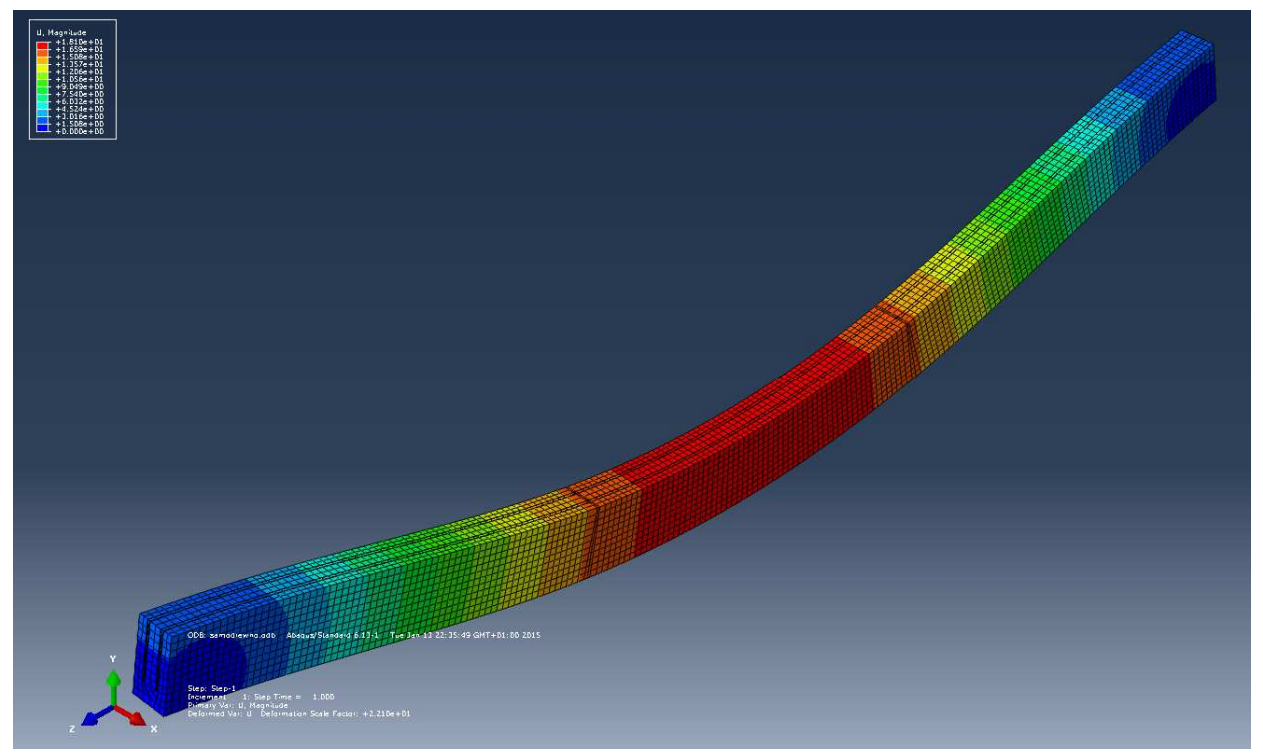

Fig. 3. Distribution of deflections in the beam of solid wood $F=30 \mathrm{kN}, \mathrm{u}_{\max }=18,5 \mathrm{~mm}$

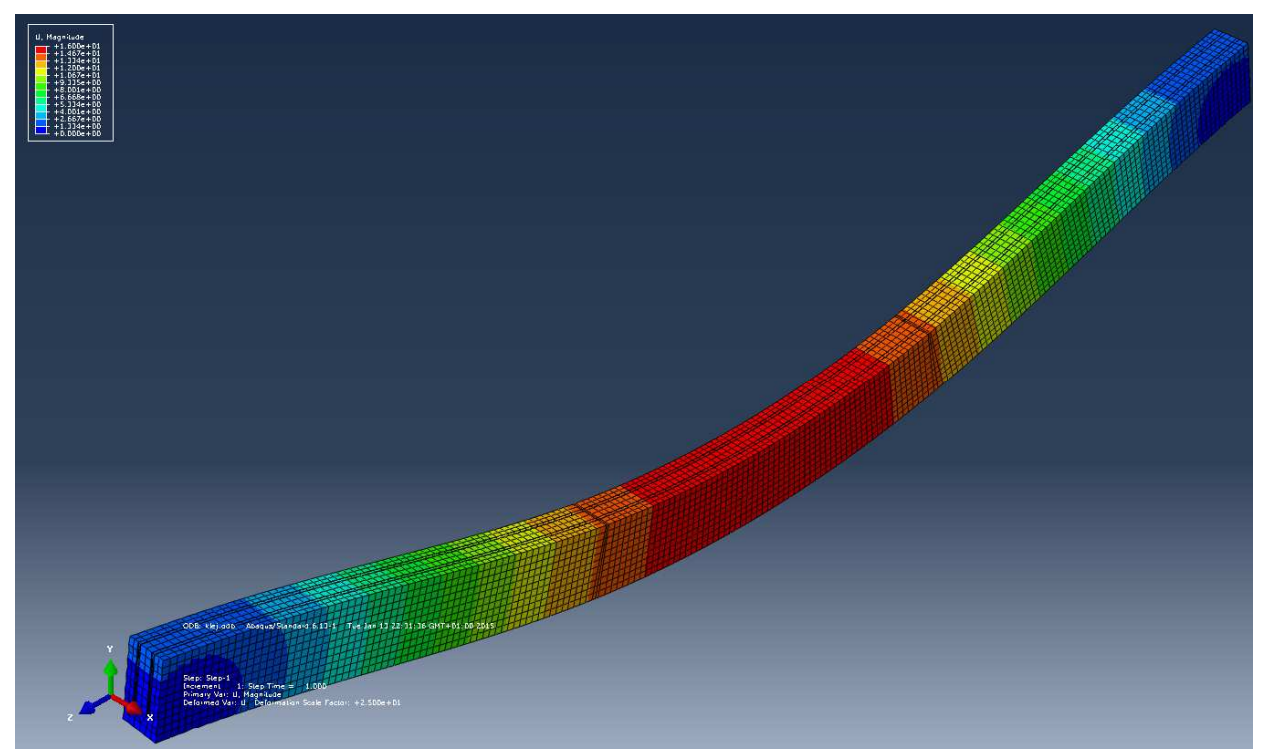

Fig. 4. Distribution of deflections in the reinforced beam $\mathrm{F}=30 \mathrm{kN}, \mathrm{u}_{\max }=12,2 \mathrm{~mm}$ 


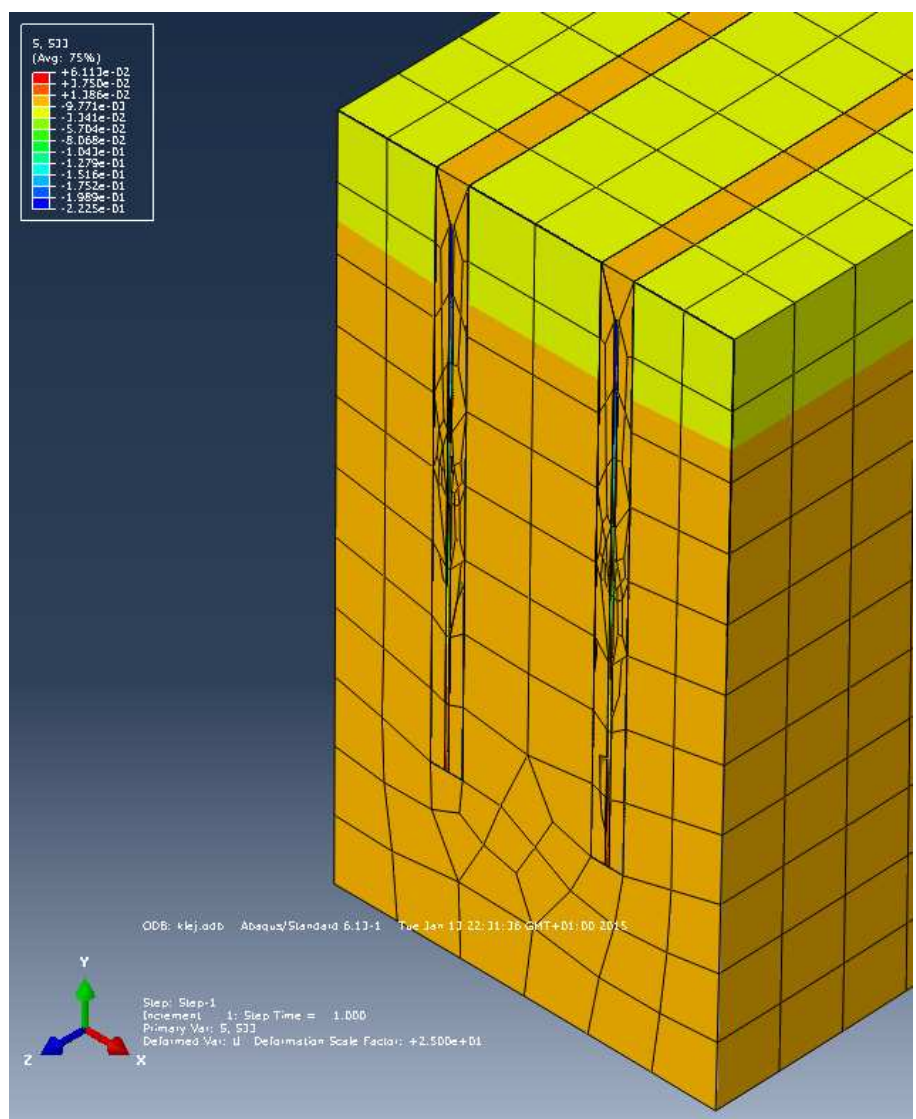

Fig. 5. Stress distribution in the direction of the beam axis at a load of $\mathrm{F}=30 \mathrm{kN}$. The cross-section in the middle of the beam span

\subsection{Analysis with long-term loads}

The results of calculations with long-term loads between 0 - 100 days of the load operation as a function of the rheological deflection increases as compared to the immediate deflection were shown in Figure 6.

In this figure were presented two rheological functions of deflection increments:

1. The function for unreinforced beam made of solid wood obtained from experimental studies presented in [5]

2. The function for reinforced beam by Fig. 2, obtained from numerical calculations carried out in the ABAQUS.

The results clearly show an exceptionally beneficial effect on strengthening of wooden beams glued from the top using composite bands and resin inclusions. 
After 100 days of operation the total load deflection are only $106 \%$ of initial deflections of the reinforced beam and up to $137 \%$ of initial deflections of the unreinforced beam. In the long run, these differences may become even much deeper.

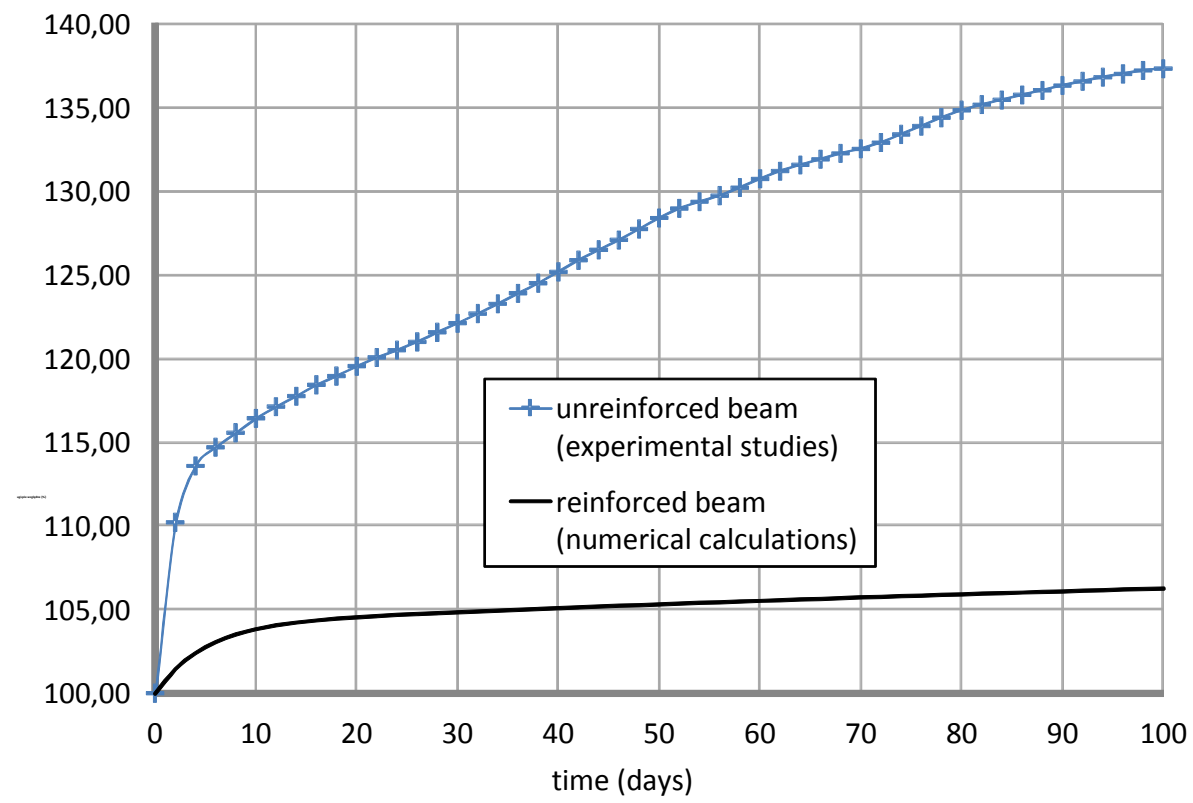

Fig. 6. The relationship of rheological deflections growths with time for reinforced beams (experimental studies) and reinforced (numerical calculations)

\section{CONCLUSIONS}

Performed numerical work allowed one to draw the following conclusions:

1. Strengthening the wooden beams with composites can reduce the rheological increases of deflections (in conducted calculations 106\% of initial reinforced beam deflections and up to $137 \%$ of initial deflections of the unreinforced beam).

2. Five-parameter rheological model is sufficient to describe the rheology of the used materials.

3. The adopted numerical model of beam work, taking into account the rheology can be used to solve a wide class of systems from beams with attached reinforcement to the typical sandwich and composite structures.

In the course of further development one should take into account the issue of work of reinforced component, which at the time of strengthening already has 
a long history of load, as well as the ability of relief and re-load of greater value than the original.

An important problem is the redistribution of stresses between the individual layers resulting from the different rheological properties of the used materials. It is also associated with widely understood optimization of the design of this type of reinforcements.

Technological considerations also play an important role, particularly quality of the glued joint. All its discontinuities may have a significant impact on the operation of the entire system.

\section{REFERENCES}

1. Jasieńko J.: Połączenia klejowe w rehabilitacji i wzmacnianiu zginanych belek drewnianych, Wrocław, Oficyna Wydawnicza Politechniki Wrocławskiej 2002.

2. Jasieńko J., Rapp P., Nowak T.: Numeryczne modelowanie rozktadów odksztatceń $i$ naprężeń $w$ belkach $z$ drewna litego wzmocnionych przy użyciu CFRP, w: VII Konferencja Naukowa Drewno i materiały drewnopochodne w konstrukcjach budowlanych, Międzyzdroje 12-13 maja 2006, Szczecin, Wydawnictwo Uczelniane Politechniki Szczecińskiej 2006, 145-152.

3. Kubik J.: Mechanika konstrukcji warstwowych, Opole, TiT 1993.

4. Mirianon F., Fortino S., Toratti T.: A method to model wood by using ABAQUS finite element software, VTT Publications 687, VTT Technical Research Centre of Finland, 2008.

5. Socha T.: Ocena wptywu obciażeń dtugotrwatych na naprężenia $i$ odksztatcenia $w$ drewnianych belkach $z$ wklejonym zbrojeniem kompozytowym, Maszynopis rozprawy doktorskiej, Uniwersytet Zielonogórski 2005.

6. Żaboklicki A.: Wzmacnianie konstrukcji drewnianych zwłaszcza zabytkowych za pomoca kompozytow polimerowych, w: Sympozjum Naukowe Drewno i materiały drewnopochodne w konstrukcjach budowlanych, Międzyzdroje 05-06 września 1996, Szczecin, Wydawnictwo Uczelniane Politechniki Szczecińskiej 1996, 353-360. 


\section{RENOWACJA I WZMACNIANIE DREWNIANYCH BELEK TAŚMAMI CFRP Z UWZGLĘDNIENIEM ZJAWISK REOLOGICZNYCH}

\section{Streszczenie}

W referacie zaprezentowano analize pracy drewnianych belek wzmocnionych wklejonymi od góry taśmami kompozytowymi i inkluzjami żywicznymi z uwzględnieniem reologii materiałów. Przedstawiono model numeryczny pracy belki wielomateriałowej obejmujący zjawiska reologiczne opisane równaniami liniowej lepkosprężystości. Zaproponowano pięcioparametrowy model reologiczny opisujacy zachowanie drewna i kleju. Do budowy modelu numerycznego wykorzystano środowisko MES SIMULIA ABAQUS, w którym przygotowano własne procedury zawierające model reologiczny, napisane w języku FORTRAN. Wyniki obliczeń porównano $\mathrm{z}$ danymi literaturowymi. Dokonano analizu celowości stosowania wzmocnień taśmami CFRP w aspekcie zjawisk reologicznych. Stwierdzono bardzo korzystny wpływ tego typu wzmocnienia na wartości reologicznych przyrostów ugięć, które są o wiele mniejsze w przypadku belek wzmocnionych w porównaniu do belek litych.

Słowa kluczowe: ABAQUS, CFRP, drewno, inkluzja żywiczna, kompozyty, konstrukcje warstwowe, MES, pełzanie, reologia, wzmacnianie

Editor received the manuscript: 15.01 .2015 